\title{
IBUFENAC (4-ISOBUTYLPHENYL ACETIC ACID)
}

BY

\author{
F. DUDLEY HART AND P. L. BOARDMAN \\ Westminster Hospital, London
}

Adams, Cliffe, Lessel, and Nicholson (1963) reported* the biological properties of a new substance, 4-isobutylphenyl acetic acid (Ibufenac). As assessed by the ultra-violet erythema test in guineapigs (Adams and Cobb, 1958), it proved to have two to four times the anti-inflammatory effect of aspirin, and its analgesic activity as measured by a modification of the method of Randall and Selitto (1957) was of the same order. Their work suggested that this substance might be a useful substitute for acetylsalicylic acid. In human subjects, after doses of $640 \mathrm{mg}$. by mouth, detectable amounts were present in the blood within 30 to 60 minutes, rising to a maximum of 2 to $4 \mathrm{mg}$. $/ 100 \mathrm{ml}$. in 2 to 4 hours, and small but detectable amounts were still present 8 hours after ingestion of the dose (Adams, 1963). Chalmers (1963) reported that Ibufenac in doses of $30 \mathrm{gr}$. daily appeared to be as effective as aspirin in doses of 60 gr. daily in the control of symptoms in patients with rheumatoid arthritis, side-effects being fewer with Ibufenac than with acetylsalicylic acid. Tudhope (1964), using the ${ }^{51}$ chromium technique previously employed by Scott, Porter, Lewis, and Dixon (1961) and Wood, Harvey-Smith, and Dixon (1962) with salicylates, found Ibufenac considerably less productive of gastro-intestinal haemorrhage, the majority of patients showing no signs of significant bleeding on this drug. It seemed that here was a likely non-toxic substitute for aspirin which could be effectively used in half the dose in patients intolerant of that drug. However, the appearance of five cases of jaundice (Morton, 1964), one in our unit, over a period of 18 months, made further approach to therapy with this substance more cautious, though all five patients made complete and uneventful recoveries on stopping the drug. Elevation of serum transaminases in about 20 to 30 per cent. of cases treated for 6 weeks or more suggested that Ibufenac was having an undesirable

* From the Research Laboratories of Boots Pure Drug Company, Nottingham. effect on the liver, most of the patients developing transaminase elevation at or after the third month of continuous therapy with 2 to $3 \mathrm{~g}$. Ibufenac daily. This finding, if considered due to significant hepatic damage, will destroy the claim advanced that Ibufenac may be used as a non-toxic aspirin substitute. We therefore present results confirming its clinical worth and await later reports and elucidation of its hepato-toxicity with interest.

An additional reason increasing, indirectly, the importance of Ibufenac is that, although hepatotoxicity may limit its obvious clinical value, there is a possibility of the development of analogues.

\section{Material and Methods}

In 62 patients with rheumatoid arthritis who were treated with Ibufenac, the sheep cell agglutination titre was positive between $1: 32$ and $1: 130,000$ in 39 and negative in $23 ; 21$ patients were admitted to hospital and 41 were seen at fortnightly or monthly intervals in the out-patient clinic. The daily dose varied between 6 and 15 tablets each containing $250 \mathrm{mg}$. Ibufenac; 49 patients received twelve tablets daily, three received fifteen, six received eight, and four received six tablets daily. Most patients received 2 to 4 weeks' therapy but in certain instances long-term treatment was continued. By March, 1964, 25 patients had received continuous therapy for longer than 3 months, the longest period of administration being 17 months.

Progress in the condition of in-patients was assessed by daily record of pain, stiffness, and morning limberingup time, with twice-weekly records of joint size, strength of grip, joint tenderness, and erythrocyte sedimentation rate (Westergren). Ibufenac and an identical placebo were administered in turn and any alteration in the above criteria of assessment was noted.

The out-patients may be conveniently divided into three groups:

Sixteen patients were assessed at each visit by the same subjective parameters as those used in the ward and were asked to compare the effect noted after taking Ibufenac with the degree of symptomatic improvement obtained from paracetamol or aspirin on a tablet for tablet basis. 
In thirteen patients, chosen because of the presence of measurable joint soft-tissue swelling, the joint size, grip strength, joint tenderness, and erythrocyte sedimentation rates were also measured.

The remaining twelve out-patients took part in a double-blind cross-over study, comparing the effect of Ibufenac, twelve $250-\mathrm{mg}$. tablets daily, with that of soluble aspirin, twelve $300-\mathrm{mg}$. tablets daily. These patients received each drug for 14 days and were assessed fully.

\section{Results}

None of the 46 patients, consisting of 21 inpatients, twelve out-patients in the double-blind study, and thirteen out-patients in whom objective criteria were measured and in whom joint size was assessed regularly, exhibited significant reduction in joint swelling as a result of treatment with Ibufenac.

Of the twelve patients who received Ibufenac $3 \mathrm{~g}$. daily and aspirin $3.6 \mathrm{~g}$. daily, double-blind, seven preferred Ibufenac and five aspirin.

In twelve of the remaining fifty patients the symptomatic improvement on Ibufenac was considered to be better than that obtained with aspirin, fifteen out of the fifty noted improvement in pain and stiffness comparable to the effect of aspirin, and eighteen preferred aspirin in the doses employed. The early development of dyspepsia in five patients prevented the assessment of Ibufenac; in the other six patients, side-effects developed sufficiently slowly for assessment of therapeutic effect to be made. Of seventeen patients who also made a comparison with paracetamol (in 500-mg. tablets), sixteen preferred Ibufenac and only one preferred paracetamol for symptomatic relief.

Long-term therapy with Ibufenac has been continued in 25 patients for 3 months or longer; the actual duration of therapy is recorded in Table $I$. No apparent tolerance has been noted in this group, but evidence of abnormal hepatic function has
TABLE I

DURATION OF THERAPY (MARCH, 1964) IN 25 PATIENTS WHO RECEIVED IBUFENAC FOR LONGER THAN 3 MONTHS

\begin{tabular}{|c|c|}
\hline No. of Months & No. of Patients \\
\hline 3 & 4 \\
\hline 4 & 2 \\
\hline 5 & 2 \\
\hline 6 & 2 \\
\hline 7 & 3 \\
\hline 8 & 3 \\
\hline 9 & 2 \\
\hline 10 & 2 \\
\hline 11 & 2 \\
\hline 12 & 1 \\
\hline 13 & 0 \\
\hline 14 & 1 \\
\hline 15 & 0 \\
\hline 16 & 0 \\
\hline 17 & 1 \\
\hline
\end{tabular}

occurred in some patients as evidenced by serum enzymatic changes.

Serial serum glutamic oxaloacetic (S.G.O.T.) and glutamic pyruvic (S.G.P.T.) measurements were made at monthly intervals in the 25 patients receiving Ibufenac for 3 months or longer. The S.G.O.T. was estimated by the method of Karmen (1955) and the S.G.P.T. by that of Wróblewski and $\mathrm{La}$ Due (1956). Normal serial values were obtained in seventeen of the 25 patients; this represents 78 months' of treatment. Of the remaining eight patients (Table II), one who developed jaundice (Case 1) will be considered later. One patient

TABLE II

ABNORMAL SERUM TRANSAMINASE LEVELS (S.G.O.T./S.G.P.T.) IN EIGHT PATIENTS ON LONG-TERM THERAPY WITH IBUFENAC

\begin{tabular}{|c|c|c|c|c|c|c|c|c|c|}
\hline \multirow{2}{*}{ Patient Number } & \multicolumn{9}{|c|}{ Months of Therapy } \\
\hline & 3 & 4 & 5 & 6 & 7 & 8 & 9 & 10 & 11 \\
\hline 1 & & & $1,245 / 392$ & & & & & & \\
\hline 2 & $70 /$ & $110 /$ & \multicolumn{3}{|c|}{ (within one week) } & & & & \\
\hline 3 & & & & $25 / 11$ & $52 / 27$ & $25 / 20$ & & & \\
\hline 4 & & & & & & $110 /$ & 94/ & $80 /$ & \\
\hline 5 & & $42 / 29$ & $24 / 11$ & 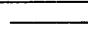 & - & $23 / 15$ & & & \\
\hline 6 & & & & & & $14 / 12$ & & $50 / 24$ & $30 / 16$ \\
\hline 7 & & $117 / 178$ & & $49 / 24$ & $24 / 12$ & & & & \\
\hline 8 & $20 / 19$ & $43 / 25$ & $29 / 9$ & 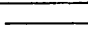 & - & $56 / 17$ & & & \\
\hline
\end{tabular}

Normal range SGOT 5-35: SGPT 5-25 photo metric units. 
(Case 2) had a rise in S.G.O.T. from normal to 70 units and then to 110 units within a week, and therapy was therefore stopped. In the remaining six patients, five (Cases $3,5,6,7$, and 8) had a transient rise but in one (Case 4), the S.G.O.T. remained elevated but gradually fell during 3 months on continuous therapy. One patient only (Case 7) had an elevated S.G.P.T. at 178 units, but this returned to normal within a month. At the times of elevated serum enzymes, liver function tests were carried out but no abnormality of serum bilirubin, flocculation tests, and alkaline phosphatase was detected.

The patient who developed jaundice was a man aged 57 who had had rheumatoid arthritis for 23 years and in whom the sheep cell agglutination titre (S.C.A.T.) was positive 1:1024. He took Ibufenac $3 \mathrm{~g}$. daily for $4 \frac{1}{2}$ months with moderate symptomatic improvement and without side-effects, but he then developed malaise, lassitude, and anorexia with occasional vomiting, flatulence, and retching, which continued for a fortnight and was followed by generalized itching and jaundice. The patient had a history of a moderately high intake of alcohol over a period of years. There was firm nontender hepatomegaly, and the signs of gross long-standing rheumatoid arthritis. Investigations indicated hepatocellular damage and a liver biopsy revealed the nonspecific changes of a mild hepatitis, and this patient was therefore considered to be suffering from Ibufenacinduced jaundice. Two features of note were the serial bilirubin and transaminase estimations during his stay in hospital. For 10 days, while still receiving Ibufenac after the onset of symptoms, the serum total bilirubin rose from 6 to $10 \cdot 2 \mathrm{mg}$. per cent., and this was followed by a fall to $3.7 \mathrm{mg}$. per cent. during the fortnight after Ibufenac was stopped. During the 10 days of continued therapy the S.G.O.T. fell from 1,245 to 392 units and the S.G.P.T. from 704 to 257 units. In the absence of cholestasis in the liver biopsy, the rise in serum bilirubin probably represents hepato-cellular damage. Liver function tests and serum transaminase estimations in this patient returned to normal within 3 months of the development of jaundice which was present clinically for about 5 weeks.

Dyspepsia occurred in eight patients but was severe in two only (Table III). All had experienced dyspepsia from drugs in the past, five while on aspirin, two from phenylbutazone, and one from paracetamol. One of those with dyspepsia from Ibufenac complained also of a swollen tongue, but when he was seen there was no clinical evidence of angioneurotic oedema. Mild flatulence was experienced by one patient, slight diarrhoea by one, and one developed a febrile reaction with worsening of arthritic symptoms on two separate occasions when given Ibufenac. This patient had a similar febrile reaction after the administration of dihydrocodeine bitartrate (D.F. 118).

TABLE III

SIDE-EFFECTS IN 62 PATIENTS ON IBUFENAC THERAPY

\begin{tabular}{|c|c|c|c|}
\hline \multicolumn{3}{|c|}{ Side-Effects } & No. of Cases \\
\hline Dyspepsia & . & . & 8 ( 2 severe) \\
\hline Flatulence & .. & . & 1 \\
\hline Mild Diarrhoea & . & . & 1 \\
\hline Fever .. & $\ldots$ & .. & 1 \\
\hline
\end{tabular}

There was a dyspeptic history in 28 out of 62 patients; this was related to aspirin in 22 , phenylbutazone in two, and both drugs in four (Table IV). This is a selected group of patients in that those with intolerance to salicylates tended to be treated with Ibufenac. Other side-effects from aspirin included tinnitus in two cases and heavy perspiration. A patient who suffered from Ménière's syndrome was also unable to take salicylates. All these patients tolerated a full dosage with Ibufenac without sideeffects, as did two who were intolerant of paracetamol.

TABLE IV

SIDE-EFFECTS IN 62 PATIENTS ON OTHER THERAPY

\begin{tabular}{|c|c|c|}
\hline Therapy & Side-Effects & No. of Cases \\
\hline Aspirin & $\begin{array}{l}\text { Dyspepsia } \\
\text { Tinnitus . . } \\
\text { Heavy Perspiration }\end{array}$ & $\begin{array}{r}22 \\
2 \\
1\end{array}$ \\
\hline $\begin{array}{l}\text { Aspirin and } \\
\text { Phenylbutazone }\end{array}$ & Dyspepsia & 4 \\
\hline Phenylbutazone & Dyspepsia & 2 \\
\hline
\end{tabular}

Barium meals were performed on four patients (Table V). In one patient with dyspepsia from Ibufenac, salicylates, and phenylbutazone, the barium meal was normal. In two patients with peptic ulcers both intolerant of soluble aspirin, no dyspepsia followed the administration of Ibufenac. A patient with a hiatus hernia experienced no sideeffects from Ibufenac but was intolerant of both salicylates and phenylbutazone.

\section{Discussion}

On the published clinical evidence (Chalmers, 1963) and the result of this trial, it seems that Ibufenac is an effective aspirin substitute. In doses half those of acetylsalicylic acid it provides comparable relief of painful symptoms and seems to be less irritant to the gastro-intestinal tract. 
TABLE V

RESULT OF BARIUM MEALS IN FOUR PATIENTS WHO HAD DYSPEPSIA WHILE ON THERAPY

\begin{tabular}{|c|c|c|c|c|c|c|c|}
\hline \multirow{3}{*}{$\begin{array}{c}\text { Case No. } \\
1\end{array}$} & \multirow{2}{*}{\multicolumn{4}{|c|}{ Barium Meal }} & \multicolumn{3}{|c|}{ Therapy } \\
\hline & & & & & Aspirin & Ibufenac & Phenylbutazone \\
\hline & Peptic Ulcer . . & . & . & . & + & - & 0 \\
\hline 2 & Peptic Ulcer . . & . & .. & .. & + & - & 0 \\
\hline 3 & Hiatus Hernia & . & . & .. & + & - & + \\
\hline 4 & Normal & . & . & .. & + & + & + \\
\hline
\end{tabular}

$+=$ Dyspepsia.

$\overline{0}=$ No dyspepsia.

The evidence that the drug is hepato-toxic in man rests on five patients out of over 750 (Morton, 1964) who developed jaundice while taking the drug. Liver biopsies in our patient with jaundice and in one other revealed no diagnostic changes, the histological picture being that of non-specific hepatitis. The main problem lies in the interpretation of the significance of the rise in S.G.O.T. which appeared in about 20 to 30 per cent. of subjects from all centres taking the drug continuously for several months (Morton, 1964). If the rise in serum transaminases reflects early liver damage consistently, then it may be possible to make this a screening test to detect patients who will develop jaundice. If this is so, liver damage may be expected to occur in about 20 to 30 per cent. of patients receiving the drug on a long-term basis. Such has not been our experience to date. The alternative possibilities are that the rise in serum transaminases may represent a transient alteration in hepatic function, or that it may derive from other sources and possess no particular significance. It should be noted in considering hepato-toxicity that, in the patient with Ibufenac-induced jaundice, during the phase of increasing liver damage with progressive elevation of the serum bilirubin, the serum transaminases gradually fell in spite of continued administration of the drug. In the group on long-term therapy, five out of six patients with raised serum transaminases were subsequently found to have normal or minimally elevated levels. In the sixth patient the S.G.O.T. rose to over 80 units for longer than 3 months but no other evidence of liver damage developed. In one patient only was there a rise in the S.G.P.T., an unexpected finding if the S.G.O.T. were of hepatic origin.

The transaminase enzymes are widely distributed in various tissues and occur, in significant concentration, in brain and cardiac muscle in addition to liver. A rise in S.G.O.T. occurs not only after myocardial infarction (Karmen, 1955) and as a result of liver disease (Wróblewski and LaDue, 1955), but also in such disorders as dermatomyositis, polymyositis, and muscular dystrophy (Mellick and Bassett, 1964); it has also been reported after the administration of morphine, salicylates, chlorpromazine, and alcohol (Wróblewski, 1959). Raised S.G.O.T. has also been reported in patients suffering from cardiac failure without infarction (Fragge, Kopel, and Iglauer, 1960; West, Gelb, Pilz, and Zimmerman, 1961), and recently with status asthmaticus (ElShaboury, Thomas, and Williams, 1964). It also follows severe exercise (Remmers and Kaljot, 1963) and has been reported during administration of the chloroquine derivative Amopyroquin (Bartholomew and Duff, 1963). Serum transaminase elevation occurs in almost all patients receiving the anabolic steroids methyltestosterone, norethandrolone, and methandrolone (Wynn, Landon, and Kawerau, 1961).

\section{Summary}

Ibufenac (4-isobutylphenyl acetic acid) is an effective substitute for aspirin when used in half the dose and is tolerated by many patients who suffer from dyspepsia while taking salicylates.

Jaundice occurred in this series in one out of 62 patients with rheumatoid arthritis treated with Ibufenac and in less than 1 per cent. of all patients treated to date; all made a complete recovery. In 25 patients on long-term therapy a rise in serum transaminase levels occurred in seven, and while the therapy was continued the levels returned towards normal in five out of six patients. It is suggested that this abnormality is not always a specific indication of liver damage. Further research work into the hepato-toxicity of this drug is indicated as it is of obvious clinical value.

We should like to thank Dr. E. V. B. Morton and Dr. S. Adams for their assistance in general and with specific problems and Boots Pure Drug Company, Nottingham, for supplies of Ibufenac (Dytransin). 


\section{REFERENCES}

Adams, S. S. (1963). Personal communication. , Cliffe, E. E., Lessel, B., and Nicholson, J. S. (1963). Nature (Lond.), 200, 271. and Cobb, R. (1958). Ibid., 181, 773.

Bartholomew, L. E., and Duff, I. F. (1963). Arthr. and Rheum., 6, 356.

Chalmers, T. M. (1963). Ann. rheum. Dis., 22, 358.

El-Shaboury, A. H., Thomas, A. J., and Williams, D. A. (1964). Brit. med. J., 1, 1220.

Fragge, R. G., Kopel, F. B., and Iglauer, A. (1960). $\quad A n n$. intern. Med., 52, 1042.

Karmen, A. (1955). J. clin. Invest., 34, 131.

Mellick, R. S., and Bassett, R. L. (1964). Lancet, 1, 904.

Morton, E. V. L. (1964). Personal communication.

Randall, L. O., and Selitto, J. J. (1957). Arch. int. Pharmacodyn., 111, 409.

Remmers, A. R., Jr., and Kaljot, V. (1963). J. Amer. med. Ass., 185, 968.

Scott, J. T., Porter, I. H., Lewis, S. M., and Dixon, A. St. J. (1961). Quart. J. Med., 30, 167.

Tudhope, G. R. (1964). Ann. rheum. Dis., 23, 30.

West, M., Gelb, D., Pilz, C. G., and Zimmerman, H. J. (1961). Amer. J. med. Sci., 241, 350.

Wood, P. H. N., Harvey-Smith, E. A., and Dixon, A. St. J. (1962). Brit. med. J., 1, 669.

Wróblewski, F. (1959). Amer. J. Med., 27, 911.

— and La Due, J.S. (1955). Ann. intern. Med., 43, 345. and - (1956). Proc. Soc. exp. Biol. (N.Y.), $91,569$.

Wynn, V., Landon, J., and Kawerau, E. (1961). Lancet, $1,69$.
Ibufenac (acide 4-isobutylphényl acétique)

RÉSUMÉ

Ibufenac (acide 4-isobutylphenyl acétique) est un remplaçant effectif de l'aspirine à la moitié de sa dose est est toléré par beaucoup de malades qui souffrent de dyspepsie lorsqu'il prennent des salicylates.

L'ictère survint dans cette série chez un sur 62 malades atteints d'arthrite rhumatismale et traités par Ibufenac et chez moins d'un pour cent de tous les malades traités jusqu'à présent; tous se sont rétablis complètement. Le taux sérique de transaminase augmenta chez 7 sur 25 malades soumis à un traitement prolongé et pendant que ce traitement continuait ce taux redevint normal chez 5 sur 6 d'entre eux. On pense que cette anomalie n'est pas toujours un signe spécifique d'une lésion hépatique. D'autres recherches sur l'hépato-toxicité de ce produit sont indiquées, car sa valeur clinique est évidente.

\section{Ibufenac (ácido 4-isobutilfenil acético)} SUMARIo

Ibufenac (ácido 4-isobutilfenil acético) es un substituto efectivo de la aspirina a la mitad de su dosis y se ve tolerado por muchos enfermos que padecen de dispepsia cuando toman salicilatos.

Una ictericia ocurrió en esta serie en uno de los 62 enfermos con artritis reumatoide tratados con Ibufenac y en menos de uno por ciento de todos los enfermos tratados hasta la fecha; todos están completamente restablecidos. Las cifras séricas de transaminasa subieron en 7 de los 25 enfermos tratados a termino largo al proseg dir el tratamiento estas cifras volvieron a lo normal en 5 de 6 enfermos. Se sugiere que esta anomalía no es siempre una indicación específica de lesión hepática. Investigaciones ulteriores sobre la hepato-toxicidad de este producto se ven indicadas, ya que su valor clínico es evidente. 